\title{
PENGELOLAAN DATA REKAM MEDIS MELALUI SISTEM PENOMORAN DAN PENYIMPANAN UNTUK MENINGKATKAN MUTU PELAYANAN KESEHATAN DI KLINIK GIGI DAN UMUM PURI MEDICAL
}

\section{MANAGEMENT OF MEDICAL RECORD DATA THROUGH NUMBER AND STORAGE SYSTEMS TO IMPROVE QUALITY OF HEALTH SERVICES IN THE DENTAL AND GENERAL PURI MEDICAL CLINIC}

\author{
Rahmi Septia Sari* \\ Program Studi Ilmu Rekam Medis, Apikes Iris, Padang \\ Email: rahmiseptiasari88@gmail.com
}

\begin{abstract}
ABSTRAK
Pemeliharaan dan pengambilan data rekam medis merupakan fungsi penting dalam pelayanan disetiap fasilitas asuhan kesehatan. Peningkatan tuntutan akan informasi kesehatan ini mengharuskan fasilitas untuk memelihara sistem informasi yang efektif dan efisien. Mengenai sistem penomoran, penyimpanan dan retensi dari manajemen rekam medis di Indonesia banyak jenisnya. Bentuk sistem penomoran dan penyimpanan yang baik merupakan tahap awal dalam pemberian pelayanan terhadap pasien. Pengambilan dan penyimpanan rekam medis yang tepat merupakan elemen penting dalam pemberian pelayanan. Perlu kehati-hatian dalam merencanakan sistem penomoran dan penyimpanan. Tujuan utama dalam melakukan pemberian penomoran adalah mengidentifikasi data pasien. Penulis berpendapat bahwa dengan menggunakan bentuk pemberian nomor metode apapun rahasia pasien dapat terjaga. Pemberian nomor ini dilakukan pada saat pasien mendaftar atau kontak dengan sarana pelayanan kesehatan. Hal tujuan utama dalam melakukan pemberian penomoran adalah mengidentifikasi data pasien. Pemberian nomor dilakukan pada saat pasien mendaftar atau kontak dengan sarana pelayanan kesehatan. Dalam kegiatan ini kami berusaha untuk mengoptimalkan sistem pelayanan kesehatan di Klinik Puri Medical melalui penyuluhan tentang sistem penomoran dan penyimpanan data Rekam Medis yang baik dan memudahkan petugas dalam pengambilan dan penyimpanan data Rekam Medis tersebut. Pelaksanaan Pengabdian kepada masyarakat ini kami menguraikan tentang pengelolaan data Rekam medis melalui tatacara sistem penomoran dan penyimpanan data Rekam Medis. Metode yang dilakukan dengan cara memberikan materi dan dipresentasikan serta didiskusikan dengan staf yang hadir dalam Pengabdian tersebut dengan beberapa tahap, antara lain dengan pemaparan materi tentang sistem penomoran dan penyimpanan yang disampaikan kepada staf/petugas bagian Rekam medik yang hadir dalam acara Pengabdian Kepada Masyarakat, setelah itu dilanjutkan dengan praktik lapangan, jika ada hal yang kurang dipahami dalam pelaksanaan maka akan dilanjutkan dengan tahap bimbingan dan konsultasi antara staf rekam medis dengan tim Pengabdian Kepada Masyarakat,tahap akhir dalam jangka beberapa minggu akan dilakukan monitoring dan evaluasi apakah ilmu yang di berikan telah teraplikasi dengan baik di klinik tersebut.
\end{abstract}

Kata kunci: Rekam Medis, Penomoran, Pengarsipan, Klinik

\section{ABSTRACT}

Maintenance and retrieval of medical record data is an important function of service in every health care facility. This increasing demand for health information requires facilities to maintain effective and efficient information systems. Regarding the numbering, storage and retention systems of medical record management in Indonesia, there are many types. The form of a good numbering and storage system is the initial stage in providing services to patients. Proper collection and storage of medical records is an important element in the delivery of services. Care needs to be taken in planning the numbering and storage system. The main purpose in numbering is to identify patient data. The author believes that by using any method of giving numbers the patient's secret can be kept. Giving this number is done when the patient registers or contacts with health care facilities. The main goal in making numbering is to identify patient data. The number is given when the patient registers or contacts with health care facilities. In this activity we are trying to optimize 
the health service system at Puri Medical Clinic through counseling about the numbering system and storing good Medical Record data and facilitate the officers in retrieving and storing the Medical Record data. This Community Service Implementation describes the management of medical record data through the procedure for numbering and storing medical record data. The method is done by providing material and presented and discussed with the staff present at the Service with several stages, including the presentation of material about the numbering and storage system that was delivered to the staff / officers of the Medical Record section who attended the Community Service event, after it is continued with field practice, if there are things that are not understood in the implementation it will be continued with the guidance and consultation phase between the medical record staff and the Community Service Team, the final stage within a period of several weeks will be carried out monitoring and evaluation whether the knowledge provided has been applied well in the clinic.

Keywords: Medical Record, Numbering, Archiving, Clinic

\section{PENDAHULUAN}

Instansi kesehatan yang memberikan pelayanan optimal dapat memberikan kepuasan dan kepercayaan pasien untuk berobat. Dengan adanya perbaikan sistempelayanan, diharapkan mampu memenuhi strategi untuk bersaing dalam pelayanan kesehatan. Perbaikan sistem dapat diwujudkan dalam bentuk sistem informasi rekam medis. Menurut [1] sarana pelayanan kesehatan wajib membuat dan merawat rekam medis dari setiap pasien yang dilayaninya. Rekam medis adalah berkas yang berisi catatan dan dokumen tentang identitas pasien, pemeriksaan pengobatan, tindakan dan pelayanan lain yang telah diberikan suatu instansi kesehatan. Salah satu instansi kesehatan yang membutuhkan rekam medis untuk mengelola data pasien adalah Rumah Sakit, Puskesmas dan Pelayanan Kesehatan Mandiri [2].

Menurut KEMENKES RI No: 128/MENKES/SK/II/2004 untuk mencapai tujuan pembangunan kesehatan diselenggarakan berbagai upaya kesehatan secara menyeluruh, berjenjang dan terpadu. Puskesmas adalah penanggungjawab penyelenggara upaya kesehatan untuk jenjang tingkat pertama. Pemeliharaan dan pengambilan data Rekam Medis merupakan fungsi penting setiap fasilitas asuhan kesehatan. Dua alat yang dipakai untuk memudahkan pemeliharaan dan pengambilan informasi kesehatan ini adalah indeks dan register. yang berfungsi untuk mengarahkan, menunjukkan, atau memudahkan rujukan. Register adalah "Catatan resmi berbagai hal, nama, atau tindakan.hampir semua indeks dan register fasilitas asuhan kesehatan dikumpul secara manual. Jenis informasi tertentu mengenai pasien dan asuhan pasien diinformasikan dari catatan medis dan ditempelkan pada lembaran kartu-kartu.

Sekarang, hampir semua indeks dan register fasilitas telah menggunakan komputer, walaupun informasi riwayat masih dalam bentuk manual. Komputerisasi informasi ini telah memajukan proses perencanaan kebutuhan masa depan, pengumpulan data, serta penelitian mengenai penyakit dan akibatnya. Sistemsistem ini memungkinkan manipulasi data yang kalau dilakukan secara manual akan sangat berat. Tersedianya informasi melalui komputer telah membawa bagian informasi kesehatan memasuki zaman informasi dan mengubah peran praktisi informasi kesehatan menjadi profesional manajemen informasi kesehatan. 
Seperti pada semua sistem lain, komponen kunci peranan ini adalah pemahaman bagaimana cara pengumpulan, keterbatasan, dan pemakaian data secara benar [2].

Peningkatan tuntutan akan informasi kesehatan ini mengharuskan fasilitas untuk memelihara sistem informasi yang efektif dan efisien dengan menggunakan indeks dan register yang baik. Penggunaan komputer yang sanggup menerima, menyimpan, dan menghasilkan data secara efisien dan mudah sekarang sudah merupakan suatu keharusan.

Mengenai sistem penomoran, penyimpanan dan retensi dari manajemen rekam medis di Indonesia banyak jenisnya. Bentuk sistem penomoran dan penyimpanan yang baik merupakan tahap awal dalam pemberian pelayanan terhadap pasien. Pengambilan dan penyimpanan rekam medis yang tepat merupakan elemen penting dalam pemberian pelayanan. Perlu kehati-hatian dalam merencanakan sistem penomoran dan penyimpanan, yang paling penting dalam menetapkan suatu sistem penomoran dan penyimpanan harus melihat keadaan fasilitas pelayanan dan jenis pelayanan kesehatan. Aktivitas penyimpanan didalamnya ada kegiatan retensi dari rekam medis.

Tujuan utama dalam melakukan pemberian penomoran adalah mengidentifikasi data pasien. Penulis berpendapat bahwa dengan menggunakan bentuk pemberian nomor metode apapun asal rahasia pasien dapat terjaga dapat dibenarkan. Pemberian nomor ini dilakukan pada saat pasien mendaftar atau kontak dengan sarana pelayanan kesehatan.Pemberian nomor dilakukan pada saat pasien mendaftar atau kontak dengan sarana pelayanan kesehatan.

Dalam hal ini kami melakukan observasi kesalah satu Pelayanan Kesehatan di Kota Padang tepatnya di bagian Pengelolaan dan pengaksesan rekam medis Klinik Puri Medical dan terlihat permasalahan tentang pelayanan dibagian rekam medis yang belum tepat dan lengkap seperti rumah sakit dikarenakan keterbatasan tenaga Perekam Medis di Klinik Puri Medical tersebut, tetapi sebaiknya aturan pengelolaan rekam medis harus dilaksanakan dengan baik. Alur pasien masuk dan keluar sebaiknya dilaksanakan sesuai prosedur yang telah ditetapkan, status pasien dikelola dan disimpan sebagaimana mestinya untuk dapat digunakan kapan saja pada saat dibutuhkan dalam pelayanan.

Klinik Puri Medical saat ini telah menerima pasien BPJS sehingga jumlah pasien yang datang untuk mendapatkan pelayanan meningkat sehingga pelaporan ke BPJS harus sesuai dengan standar yang ada di BPJS. Dalam hal ini kami ingin memberikan sosialisasi tentang pengelolaan dan pemeliharaan data rekam medis yang bertujuan untuk meningkatkan pelayanan yang lebih baik dan terdokumentasi terhadap staf medis yang ada di Klinik Puri Medical khususnya tenaga Rekam Medis.

\section{METODE PELAKSANAAN KEGIATAN}

Pelaksanaan kegiatan terdiri dari beberapa tahap:

1. Materi Kegiatan

Materi dalam kegiatan pengabdian masyarakat ini adalah tentang tata cara 
pengelolaan data Rekam Medis untuk meningkatkan pelayanan melalui pengelolaan sistem penomoran dan penyimpanan Rekam Medis di Klinik Puri Medical melalui:

a) Cara pemberian nomor Rekam Medis yang memudahkan petugas untuk mengidentifikasi data pasien.

b) Cara penyimpanan data Rekam Medis.

c) Bagaimana cara Pengelolaan data Rekam Medis yang mampu untuk meningkatkan pelayanan yang lebih baik dan terdokumentasi.

2. Metode Pelaksanaan

Dalam Pelaksanaan Pengabdian kepada masyarakat ini kami menguraikan tentang pengelolaan data Rekam medis melalui tatacara sistem penomoran dan penyimpanan data Reakam Medis. Metode Pelaksanaan Pengabdian kepada masyarakat dilakukan dengan cara memberikan materi dan dipresentasikan serta didiskusikan dengan staf yang hadir dalam Pengabdian tersebut dengan beberapa tahap:

a. Pendidikan tentang pengelolan data Rekam medis

Pemaparan materi tentang pengelolaan data Rekam sistem penomoran dan penyimpanan serta pengelolaan data Rekam medis yang dilakukan dengan cara memberikan informasi kepada pemberi pelayanan kesehatan khususnya bagian Rekam Medis pada kegiatan Pengabdian kepada masyarakat di Klinik Puri Medical.

b. Praktik Lapangan
Praktik lapangan dilakukan dengan melakukan kegiatan praktek bagaimana cara pmbuatan nomor Rekam medis dan penyimpanannya dengan cara menggunakan sistem penomoran, Straight, Midle dan Terminal. Serta bagaimana cara pengelolaan data Rekam Medis yang baik.

c. Bimbingan dan Konsultasi

Bimbingan dan konsultasi dilakuka pada saat mendampingi petugas Pelayanan Kesehatan dalam melayani pasien pada saat admisi atau mendaftar untuk berobat ke puskesmas. Sebagai Tim Pengmas memberikan arahan dan bimbingan ketika ada staf pelayanan kesehatan yang tidak paham dalam pembuatan nomor Rekam medis berdasarkan materi yang telah dipaparkan.

\section{d. Monitoring dan Evaluasi}

Memantau dan melakukan perbaikan apabila dalam pelaksanaan kegiatan pengabdian kepada masyarakat di Klinik Puri Medical apakah telah terimplementasikan materi yang diberikan terhadap petugas Rekam Medis Klinik Puri Medical tersebut.

Adapun tugas dari masing-masing anggota yang ada dalam Tim Pengabdian Kepada Masyarakat Ini antara lain:

a. Moderator: Mahasiswa

1. Membuka dan menutup acara

2. Memperkenalkan diri

3. Menetapkan tata tertib acara penyuluhan

4. Memimpin diskusi 
5. Memimpin atau memandu jalannya kegiatan

6. Mengontrak waktu penyuluhan

7. Menyimpulkan kegiatan di akhir penyuluhan

b. Penyuluh: Rahmi Septia sari

1. Menyajikan materi penyuluhan

2. Menggali pengetahuan audience mengenai topik penyuluhan

3. Memberi reinforcemen sesuai dengan respon klien

4. Memberikan pengertian tentang hal-hal yang tidak di pahami klien

5. Bersama fasilitator menjalin kerja sama dalam acara penyuluhan

c. Observer : Mahasiswa

1. Mengamati jalannya kegiatan

2. Mencatat prilaku verbal dan non verbal peserta kegiatan

3. Mencatat jumlah audience yang hadir

4. Mencatat tanggapan-tanggapan yang dikemukakan audience

5. Mencatat penyimpangan acara penyuluhan

6. Membuat laporan hasil kegiatan

7. Evaluasi Kegiatan

d. Fasilitator: Rahmi Septia Sari dan Mahasiswa

1. Memfasilitasi jalannya acara dan kegiatan persiapan dan pelaksanaan

2. Memotivasi peserta kegiatan dalam bertanya.

3. Memfasilitasi audience yang kurang aktif

4. Mampu memotivasi klien untuk kesuksesan acara

5. Dapat mengatasi hambatan-hambatan yang terjadi dari dalam atau dari luar.
6. Bersama moderator menjalin kerja sama dalam menyajikan materi penyuluhan

\section{HASIL DAN PEMBAHASAN}

Dalam Pengabdian Kepada Masyarakat di bidang Rekam Medis terlebih dahulu kami tim PKM melakukan observasi dan mewawancarai staf bagian Rekam Medis dan diperoleh informasi bahwa:

1. Klinik puri medical untuk pengelolaan data Rekam Medis memakai sistem penomoran keluarga.

2. Penyimpanan data Rekam Medis dalam satu keluarga disimpan pada satu folder saja dan diberikan satu nomor dan sebagai penanda antara kepala keluarga dengan anak diberikan nomor penanda, kepala keluarga nomor 01, pasangan 02, anak ke satu 03, seperti itu selanjutnya.

3. Lembar formulir Rekam medis yang digunakan terbuat dari bahan kertas yang lunak dan apabila terkena air akan mudah sobek dan sebagian rekam medis pasien masih ada yang tidak memiliki map untuk pelindung Rekam Medis.

4. Pola Pengarsipan yang digunakan di klinik puri medical adalah pola pengarsipan sentralisasi karena semua rekam medis hanya tersimpan pada satu tempat saja.

5. Rekam Medis Pasien yang ada pada rak penyimpanan di klinik puri medical tidak ada retensi $\mathrm{RM}$ non aktif, bagian $\mathrm{RM}$ klinik belum ada melakukan pemusnahan terhadap Rekam Medis yang tidak aktif selama klinik beroperasi sebagai fasilitas pelayanan kesehatan semenjak tahun 2008.

Menurut [3] setiap fasilitas pelayanan 
kesehatan mempunyai kewajiban untuk mengelola dokumen rekam medis. Antara lain pengelolaan sistem penyimpanan dan penomoran yang digunakan dalam pengarsipan rekam medis. Sehingga rekam medis terpelihara dengan baik.

Dokumentasi kegiatan pada gambar 1-5 dibawah ini:

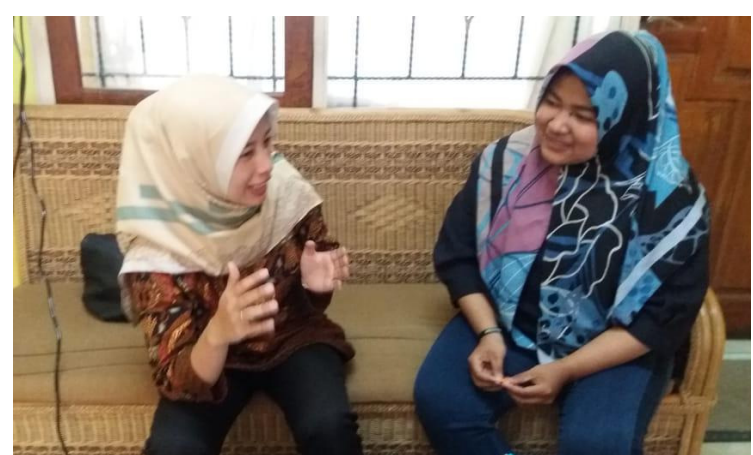

Gambar 1 : Pemaparan Materi Secara Langsung

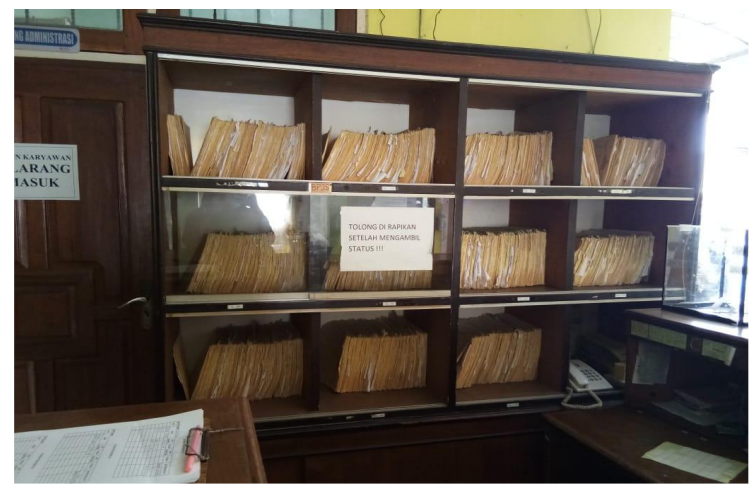

Gambar 2 : Lemari Penyimpanan RM

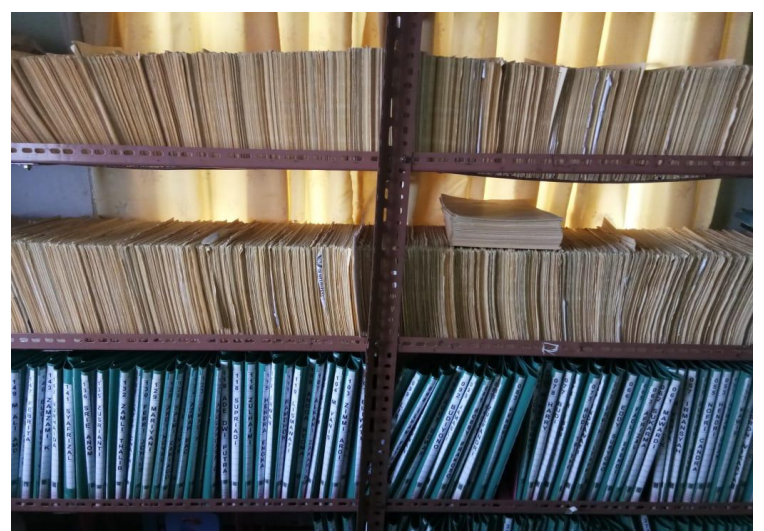

Gambar 3 : Rak Penyimpanan RM

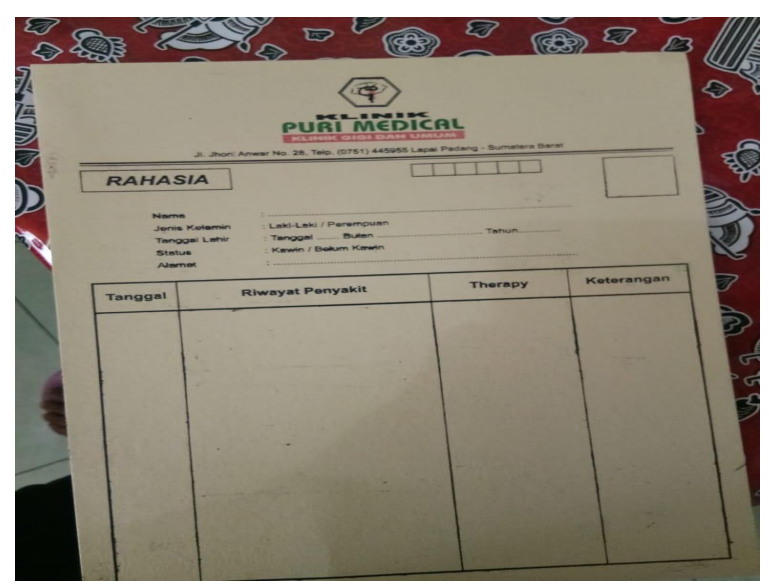

Gambar 4 : Formulir Rekam Medis

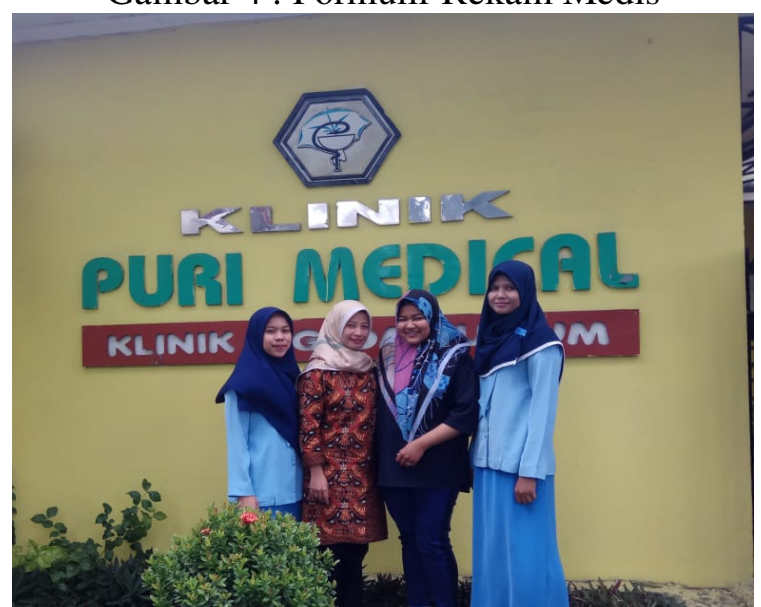

Gambar 5 : Narasumber dan Perwakilan Petugas Rekam Medis

\section{KESIMPULAN}

Dengan dilakukan PKM di Klinik Puri medical dapat menambah wawasan staf bagian rekam medis tentang sistem penomoran rekam medis yang terdiri dari sistem penomoran serial, unit, dan serial unit. Sehingga dapat meningkatkan tertib penyimpanan rekam medis yang memudahkan petugas untuk mencari Rekam medis pasien. Penjelasan narasumber tentang kebijakan mengenai lama penyimpanan rekam medis sesuai aturan adalah 5 tahun dan untuk RM operasi adalah 10 tahun semenjak rekam medis non aktif, data tersebut sudah boleh dimusnahkan atau diinaktifkan yang dikeluarkan hanya resume dan inform consent. Lokasi penyimpanan RM inaktif harus 
dipisahkan pada area fasilitas lain, disimpan secara komersial dan dihancurkan sesuai aturan. Pola pengarsipan RM terdiri dari sentral dan desentralisasi, pola pengarsipan yang di gunakan di klinik puri medical adalah pola sentralisasi dimana RM pasien tersimpan pada satu lokasi saja sehingga memudahkan petugas mencari RM pasien. Pelaksanaan PKM di klinik Puri Medical hendaknya dapat menambah wawasan dan pengetahun petugas kesehatan khususnya bagian rekam medis tentang sistem penomoran dan penyimpanan rekam medis pasien untuk meningkatkan mutu pelayanan kesehatan. Bagian fasilitas rekam medis di klinik Puri medical hendaknya dapat mengaplikasikan ilmu dan wawasan yang telah diberikan atau dipaparkan Tim PKM Apikes Iris. Sistem penomoran yang digunakan di klinik Puri medical berupa sistem Family Number hendaknya dapat dilakukan sesuai aturan yang telah ditentukan.

\section{UCAPAN TERIMAKASIH}

Terimakasih penulis ucapkan kepada segenap akademika Apikes Iris dan pimpinan Klinik Puri Medical yang telah mengizinkan kami untuk melakukan Pengabdian Kepada Masyarakat kepada tim Rekam Medis.

\section{DAFTAR PUSTAKA}

[1] Indradi S. Rano (2017). Rekam Medis. Jakarta: Universitas Terbuka.

[2] Depkes RI. (2006.). Pedoman Penyelenggaraan dan Prosedur Rekam Medis Rumah sakit di Indonesia. Jakarta:Depkes RI.

[3] Savitri, Budi (2009). Manajemen unit kerja rekam medis. Yogyakarta : Quantum Sinergis Media.

[4] Hatta. (2012). Pedoman Manajemen Informasi Kesehatan di Sarana pelayanan Kesehatan. Jakarta:. UI Press

[5] Kemenkes RI. (2008). Peraturan menteri Kesehatan No 269 Tentang Rekam Medis. Jakarta.

[6] Kemenkes RI. (2009). Undang-Undang No.40 Tentang Kesehatan. Jakarta. 